\title{
低エネルギー質量分離イオンビーム照射装置を用いた ネオンによる金のスパッ夕率の測定*
}

日根 清裕 $* 1$. 吉村 智*1 . 木内 正人 $* 1, * 2 \cdot$ 浜口 智志*1

\section{Measurement of $\mathrm{Au}$ Sputtering Yields by Neon with Low-Energy Mass Analyzed Ion Beam System}

\author{
Kiyohiro HINE*1, Satoru YOSHIMURA*1, Masato KIUCHI*1,*2 and Satoshi HAMAGUCHI*1 \\ ${ }^{* 1}$ Center for Atomic and Molecular Technologies, Graduate School of Engineering, Osaka University, \\ 2-1 Yamadaoka, Suita, 565-0871 Osaka \\ *2National Institute of Advanced Industrial Science and Technology (AIST), \\ 1-8-31 Midorigaoka, Ikeda, 565-8577 Osaka
}

(Received November 7, 2006, Accepted January 13, 2007)

\begin{abstract}
The Au sputtering yields by Ne ions were measured in the range of low injection energy with a low-energy mass analyzed ion beam system. For the ion beam characterization, the mass and energy spectra of the Ne ion beams were measured with a plasma process monitor (Balzers, PPM421) and it was found the Ne beams were essentially monochromatic. The ion beam was injected into an Au thin film prepared on a quartz crystal microbalance $(\mathrm{QCM})$ and its sputtering yield was evaluated from the Au mass decrement. It has been found that the measured $\mathrm{Au}$ sputtering yields by $\mathrm{Ne}$ ion beams in the energy range of 100-200 eV approximately agree with the previously reported corresponding values. The sputtering yields were also measured for the injection energies below $100 \mathrm{eV}$. The threshold energy for Au sputtering by Ne estimated from the low energy data is $35 \mathrm{eV}$.
\end{abstract}

\section{1. はじめに}

金などの貴金属は，近年，半導体の電極材料として広く使 用されており，その形成方法として，希ガスを用いたスパッ タ蒸着が広く利用されている，従って，金の堆積率及び希ガ スイオンによるスパッタ率の測定1) は, 応用上非常に重要で ある. 我々はこれまでに, 低エネルギー質量分離イオンビー ム照射装置2)用いて，低エネルギー領域での金の堆積率の 測定 ${ }^{3)}$ を行った。本装置は，イオン源において生成したイオ ンを高電圧で引き出し, 質量分離を行い, 照射する直前で減 速することによって，所定のエネルギーのイオンビームを取 り出すことができる.

希ガスによる金のスパッタ率に関して, これまでに, ネオ ンについて $100 \mathrm{eV}$ から50 keV のエネルギー領域でのスパッ タ率の測定結果は, 数例1)4-7)報告されている. しかしなが ら，それらの測定では，イオンのエネルギースペクトルが示 されて抢らず, 真のエネルギ一值やエネルギースペクトルの 幅など，入射イオンビームの質が明らかでない。また，100 $\mathrm{eV}$ 以下のエネルギーの低い領域での測定結果については少 数の報告のみである ${ }^{1,4)}$.

そこで我々は，本装置を用いて，30 eV から $200 \mathrm{eV}$ の工 ネルギー領域におけるネオンイオンによる金のスパッタ率測 定を行った. 本論文では，その測定結果について報告する.

* 平成18年11月 9 日 第47回真空に関する連合講演会で発表

*1 大阪大学大学院工学研究科原子分子イオン制御理工学センター （干565-0871 大阪府吹田市山田丘 2-1）

*2 独立行政法人産業技術総合研究所 ( 緑丘 1-8-31)

\section{2. 実 験方 法}

本実験で用いた，低エネルギー質量分離イオンビーム照射 装置の構成をFig. 1 に示す. 本装置にはフリーマン型イオ ン源が搭載されており, 高温のタングステンを用いて, 熱電 子を取り出し電子衝撃により原料ガスをイオン化している. 発生させたネオンのイオンは, 高電圧 $(-15 \mathrm{kV})$ を印加す ることによって, 高速で引き出される. 引き出したイオン ビーム中には, 残留ガスなどの不純物イオンが混在してい る.これらを除去するために, 電磁石を利用した扇形質量分 離器を通して, 不純物の混ざらないイオンビームを取り出し ている.こうして得られたイオンビームは, 残留ガスとの衝 突による荷電交換などで発生した高速中性粒子を取り除くた めに, 静電偏向を行ったのちに成膜室に輸送される. 成膜室 のビーム射出口の直前には, 減速電極が設置されており, こ こでイオンビームを所定のエネルギーまで減速し, 水晶振動 子またはファラデーカップに照射される.

成膜室の概略図を，Fig. 2 に示す。成膜室にはファラ

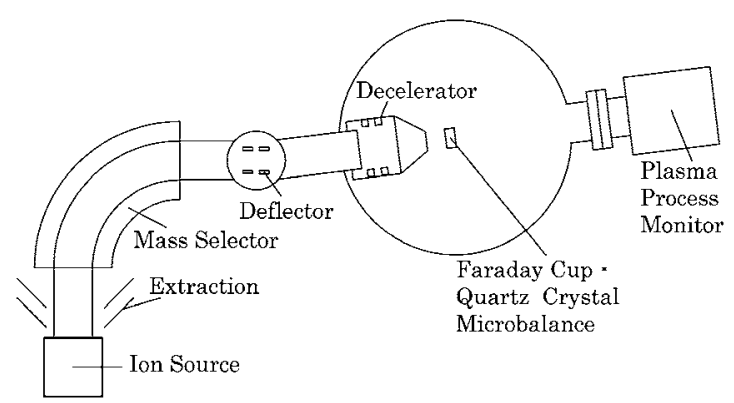

Fig. 1 Schematic diagram of the Low-Energy Mass Analyzed Ion Beam system. 


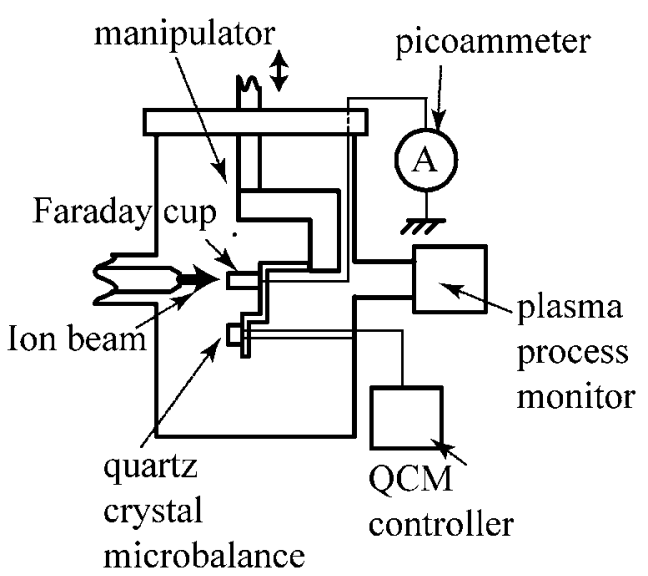

Fig. 2 Schematic diagram of the measurement system for the Au sputtering yields.

デーカップと水晶振動子が，上下に並べて設置されている. これらの位置は，マニピュレーターを用いた真空外からの操 作によって，上下方向に自在に移動させることができる．ス パッタの測定には, 水晶発振式膜厚計 (ULVAC, CRTM9000）と専用センサー（ULVAC, CRTS-0）を用いた。水 晶板は, AT カットクリスタルの表面に電極として金が蒸着 されてあるもので，共振周波数は $5 \mathrm{MHz}$ である．膜厚測定 の分解能は, 堆積物質の質量密度が $1.0 \mathrm{~g} / \mathrm{cm}^{3}$ の場合に $0.000550 \mathrm{~nm}$ である.ビーム照射実験に先立ち, この水晶板 上にさらに膜厚約 $1 \mu \mathrm{m}$ の金を真空蒸着してある．また，フ アラデーカップは, 真空導入端子を介してピコアンメータ (KEITHLEY, 6485) と接続されており，イオンビームの電 流量を測定することができる.

成膜室にはプラズマプロセスモニター (Balzers, PPM421) も設置されて抢り，これを用いることで，イオンビームに含 まれる粒子の質量スペクトル，イオンビームのエネルギース ペクトルを測定することができる.

本実験は以下の手順で行った。まず，照射するイオンビー ムのエネルギースペクトルを，プラズマプロセスモニターを 用いて測定した，次に，水晶板にイオンビームを照射する前 に, ファラデーカップにイオンビームを照射して, 電流量を 測定した。そして，水晶板に一定時間イオンビームを照射 し, スパッタリングを行った。照射後, 再びイオンビームの 電流量を測定し，スパッタリングの前後で大きな変化がない ことを確認した．水晶発振式膜厚計で測定された質量減少量 からスパッタされた原子数を，イオンビーム電流量と照射時 間から入射イオン数を計算し，それらを用いてスパッタ率を 求めた。

なお，照射されるイオンビームの径は， $100 \mathrm{eV}$ の場合を 例にとると, 半值幅で約 $18 \mathrm{~mm}$ である. これは, 水晶振動 子の照射 (蒸着) 面の径 $(7.5 \mathrm{~mm})$ より十分に大きく, 水 晶振動子には，ほほ均一なイオンビームが照射されている.

\section{3. 実験 結果}

スパッタ率の測定に先立って, 入射イオンビームの質を評 価するため，エネルギースペクトルを測定した結果を Fig. 3 に示す. Fig. 3 には設定電圧が (a) $50 \mathrm{~V}$, (b) $100 \mathrm{~V}$, (c) 150
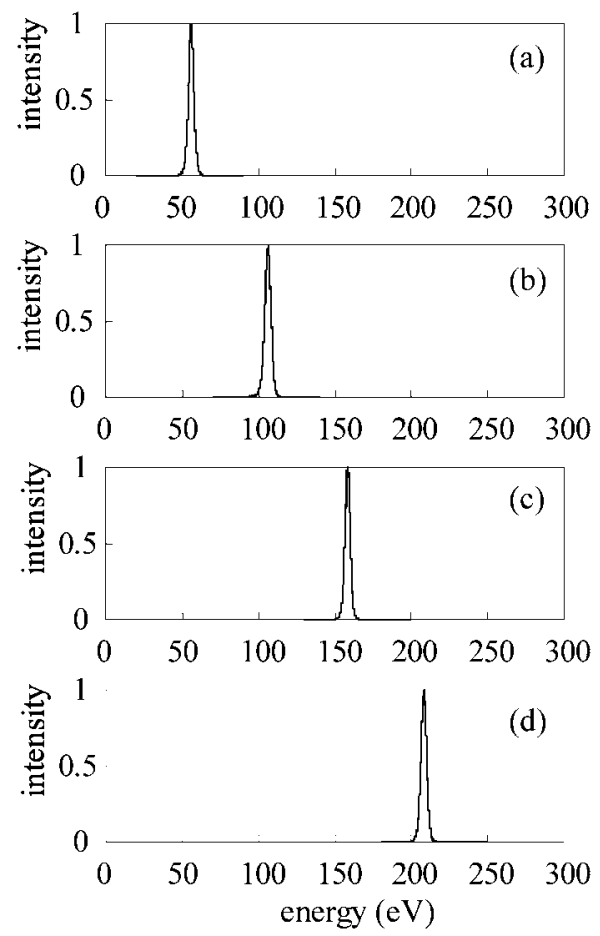

Fig. 3 Energy distributions of Ne ions measured by the plasma process monitor. The bias voltages are (a) $50 \mathrm{~V}$, (b) 100 $\mathrm{V}$, (c) $150 \mathrm{~V}$, and (d) $200 \mathrm{~V}$.

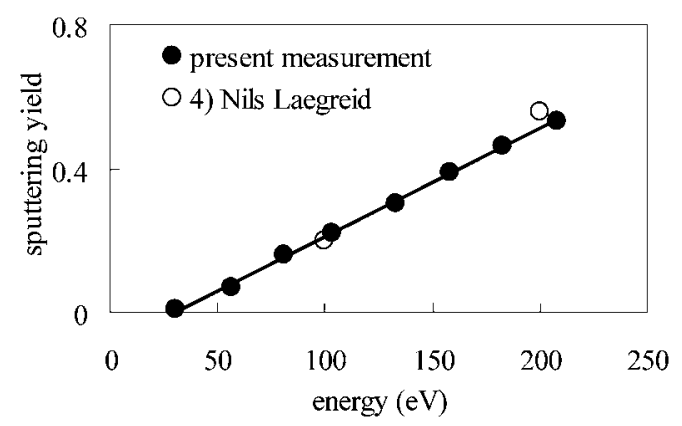

Fig. 4 Sputtering yields of $\mathrm{Au}$ by $\mathrm{Ne}$ ion beams as a function of the ion energy (the closed circles) and reported results) the open circles $)^{4)}$.

$\mathrm{V}$, (d) $200 \mathrm{~V}$ の場合の, プラズマプロセスモニターで測定し たイオンビームのエネルギースペクトルを例として示してい る、いずれの場合も, プラズマポテンシャルの影響によっ て, 減速電極の設定值に比べ約 $5 \mathrm{eV}$ の高エネルギー側への シフトが見られた. また, スペクトルの半值幅は約 $5 \mathrm{eV}$ であった。

ネオンビームを照射した場合の，スパッタ率と粒子エネル ギーの関係を, Fig. 4 に示す. エネルギーの低い領域に打 けるスパッタ率を測定した結果, エネルギーと共にスパッタ 率が単調増加していくことが分かった。 また, 得られた結果 から推測されるスパッタの閾值エネルギーは約 $35 \mathrm{eV}$ であっ た. な抢, Fig. 4 には比較のために, 過去の文献值 ${ }^{4}$ を併記 している. Fig. 4 から分かるように, $100 \mathrm{eV}$ 以上における 測定結果は過去の文献値と矛盾しない。 


\section{4. まとめ}

低エネルギーイオンビーム照射装置を用いて，ネオンによ る金のスパッタ率の測定を行った。

イオンビームのエネルギースペクトルを，プラズマプロセ スモニターを用いて測定した結果, 設定電圧に比べ, ピーク エネルギーの高エネルギー側へのシフトが見られた.

ネオンビームのエネルギーを変化させて照射し，金のスパ ッタ率を低エネルギー領域で測定した. $100 \mathrm{eV}$ 以上のエネ ルギーに抢ける結果は, 過去の文献值とよく一致しており, $100 \mathrm{eV}$ 以下のエネルギーに打けるスパッタ率も測定するこ とができた. 得られた值から推測されるスパッタの閾值エネ ルギーは，約 $35 \mathrm{eV}$ であった。
謝辞

本研究を行うにあたり, その一部は, 文部科学省科学研究 費補助金（基盤研究 B，課題番号17340174）の援助によっ て行われた.

\section{〔文献〕}

1) Y. Yamamura and H. Tawara: Atom. Data Nucl. Daata Tabl., 62 (1996) 149.

2）松本貴士，美本和彦，吉川貴文，木内正人，後藤誠一，大庭昌 俊, 阿川義昭：真空, 42 (1999) 341.

3）日根清裕, 吉村 智, 前田拓也, 木内正人, 浜口智志 : 真空, 49, (2006) 177.

4) Nils Laegreid and G. K. Wehner: J. Appl. Phys., 32 (1961) 365.

5) O. Almen and G. Bruce: Nucl. Instr. Meth., 11 (1961) 257.

6) A. Oliva-Florio, R. A. Baragiola, M. M. Jakas, E. V. Alonso and J. Ferron: Phys. Rev. 35 (1987) 2198.

7) E. P. EerNisse: Appl. Phys. Lett., 29 (1976) 14.

8) T. Matsumoto, K. Mimoto, S. Goto, M. Ohba, Y. Agawa and M. Kiuchi: Rev. Sci. Instrum., 71 (2000) 1168. 